\title{
Prevalence and risk factors for bovine tuberculosis in the State of Bahia, Brazil
}

\section{Prevalência e fatores de risco para tuberculose bovina na Bahia, Brasil}

\author{
Luciana Bahiense ${ }^{1}$; Luciana Niedersberg de Ávila²; Maria Emília Bavia ${ }^{3}$; Marcos \\ $\mathrm{Amaku}^{4}$; Ricardo Augusto Dias"; José Henrique Hildebrand Grisi-Filho4; \\ Fernando Ferreira ${ }^{4}$; Evelise Oliveira Telles ${ }^{4}$; Vitor Salvador Picão Gonçalves ${ }^{5}$; \\ Marcos Bryan Heinemann ${ }^{4}$; José Soares Ferreira Neto ${ }^{4 *}$
}

\begin{abstract}
An epidemiological study was carried out in order to characterize the bovine tuberculosis situation and to support the planning and implementation of the National Program for the Control and Eradication of Bovine Tuberculosis in the State of Bahia, owing to the importance of the disease in causing economic burdens and its impact on public health. The State was divided into four regions. In each region, properties were randomly chosen and, a pre-established number of animals was also randomly selected; these animals then subjected to the intradermal comparative cervical tuberculin diagnostic test. Animals with inconclusive test results were retested with the same diagnostic procedure within a minimum interval of 60 days. Within each sampled property, a questionnaire was administered to verify possible risk factors for the disease. In the State, the prevalence of infected herds was $1.6 \%$ [1.0-2.6] and that of infected animals $0,21 \%[0,07 ; 0,60]$. In the regions, the prevalence of infected herds and infected animals were, respectively, $2,0 \%[1,0 ; 4,2 \%]$ and $2,0 \%[1,0 ; 4,2 \%]$ in region $1 ;, 2,9 \%[1,5 ; 5,5]$ and $0,66 \%[0,20 ; 2,16]$ in region $2 ; 0,3 \%[0,04 ; 2,1]$ and $0,02 \%[0,002 ; 0,12]$ in region $3 ;$ and $0,6 \%[0,2 ; 2,5]$ and $0,05 \%[0,01 ; 0,20]$ in region 4 . The risk factors associated with tuberculosis infection were dairy farm (odds ratio $[\mathrm{OR}]=9.72$ ) or mixed farm $(\mathrm{OR}=6.66)$, and size of herd $\geq 18$ cows $\geq 24$ months of age $(\mathrm{OR}=8.44)$. In conclusion, it is recommended that the State of Bahia implement a surveillance system for the detection of herds with bovine tuberculosis to certifying them in free herds, with special attention to dairy properties, and develop a solid program of health education so that producers test animals for bovine tuberculosis before introducing them into their herds.
\end{abstract}

Key words: Bovine tuberculosis. Prevalence. Risk factors. Bahia. Brazil.

\section{Resumo}

Em virtude da importância da tuberculose bovina como enfermidade causadora de prejuízos econômicos, o impacto em saúde pública e visando apoiar o planejamento e execução do Programa Nacional de Controle e Erradicação da Tuberculose Bovina no Estado da Bahia, foi realizado estudo epidemiológico

${ }^{1}$ Médica Veterinária Agência Estadual de Defesa Agropecuária da Bahia, Salvador, BA, Brasil. E-mail: lubahiense@hotmail.com

2 Médica Veterinária. Programa Nacional de Controle e Erradicação da Brucelose e Tubercu $\neg$ lose Bovina (PNCEBT), Agência Estadual de Defesa Agropecuária da Bahia (ADAB), Secretaria de Agricultura do Estado da Bahia, Salvador, BA, Brasil. E-mail: luciana.avila@adab.ba.gov.br

${ }^{3}$ Prof ${ }^{a}$, Escola de Medicina Veterinária e Zootecnia, Universidade Federal da Bahia, UFBA, Salvador, BA, Brasil. E-mail: baviame@gmail.com

${ }^{4}$ Profs., Faculdade de Medicina Veterinária e Zootecnia, Universidade de São Paulo, USP, São Paulo, SP, Brasil. E-mail: grisi@ vps.fmvz.usp.br; fernando@vps.fmvz.usp.br; amaku@vps.fmvz.usp.br; dias@vps.fmvz.usp.br; evelise@vps.fmvz.usp.br; marcosbryan@usp.br; jsoares@vps.fmvz.usp.br

5 Prof., Faculdade de Agronomia e Medicina Veterinária, Universidade de Brasília, UNB, Brasília, DF, Brasil. E-mail: vitorspg@ unb.br

* Author for correspondence 
para caracterizar a situação da enfermidade no estado. O Estado foi estratificado em quatro regiões. Em cada região, propriedades foram sorteadas aleatoriamente e, dentro dessas, escolheu-se de forma também aleatória um número pré-estabelecido de animais, os quais foram submetidos ao teste tuberculínico Cervical Comparativo. Os animais que resultaram inconclusivos foram retestados com o mesmo procedimento diagnóstico em intervalo mínimo de 60 dias. Em cada propriedade amostrada aplicou-se um questionário para se verificar possíveis fatores de risco para a doença. No Estado, a prevalência de focos foi de $1,6 \%[1,0 ; 2,6 \%]$ e a de animais $0,21 \%[0,07 ; 0,60]$. Nas regiões, as prevalências de focos e de animais foram, respectivamente de $2,0 \%[1,0 ; 4,2 \%]$ e $0,08 \%[0,035 ; 0,17]$ na região $1,2,9 \%[1,5$; $5,5]$ e $0,66 \%[0,20 ; 2,16]$ na região $2,0,3 \%[0,04 ; 2,1]$ e $0,02 \%[0,002 ; 0,12]$ na região 3 e $0,6 \%[0,2$; $2,5]$ e $0,05 \%[0,01 ; 0,20]$ na região 4 . Os fatores de risco associados a condição de foco foram: ser propriedade leiteira $(\mathrm{OR}=9,72)$, ser propriedade mista $(\mathrm{OR}=6,66)$ e tamanho do rebanho $\geq 18$ fêmeas $\geq 24$ meses $(\mathrm{OR}=8,44)$. Concluindo, recomenda-se que o Estado da Bahia implemente um sistema de vigilância para detecção e saneamento dos focos de tuberculose bovina, com especial atenção para as propriedades produtoras de leite, e que desenvolva uma sólida ação de educação sanitária para que seus produtores passem a testar os animais para tuberculose bovina antes de introduzi-los em seus plantéis.

Palavras-chave: Tuberculose bovina. Prevalência. Fatores de risco. Bahia. Brasil.

\section{Introduction}

The State of Bahia comprises $565,000 \mathrm{~km}^{2}$, is located in the northeast region of Brazil, and has a population of around 14 million inhabitants. It is composed of 417 municipalities, primarily (69\%) located in the semiarid region (IBGE, 2011).

The Bahian economy is composed of agriculture, livestock, industry, mining, tourism, and services. Within this economy, bovine livestock occupies an important role. The cattle herd in the State comprises approximately 12 million head. Currently, extensive farming predominates in the great majority of properties $(85 \%)$, with an emphasis on beef cattle. The center-north, center-south and northeast areas are the most dedicated to livestock, and the State is the largest producer of beef in the northeast region of the country. In recent years, the Bahian livestock sector has experienced a gradual modernization of its production techniques.

In 2001, the State was certified for the first time as free of foot and mouth disease following a vaccination campaign by the International Organization for Animal Health (OIE), losing the status in 2005 and recovering it in 2008. Also in 2001, the deployment of the National Program for the Control and Eradication of Animal Brucellosis and Tuberculosis (PNCEBT) was initiated. In 2004, the prevalence of bovine brucellosis was estimated at $4.2 \%$ of infected herds of $0.66 \%$ of positive animals (ALVES et al., 2009).

The records of the occurrence of bovine tuberculosis in the State are scarce and come from small studies. Costa et al. (1995/1996) found that $5.5 \%$ of animals had positive reactions to the tuberculin test in the municipality of Alagoinhas, located in the northeast region of the State. Ribeiro et al. (2003), reported a rate of $2.8 \%$ of animals positive to the tuberculin test and a rate of $10.6 \%$ of infected properties in the municipality of Ilhéus, located to the eastern part of the State. That study was performed in $21.7 \%$ of breeding properties, with the equivalent of $16 \%$ of adult cows. In 2010, Costa et al. obtained seven isolates of Mycobacterium bovis (M. bovis) from 43 carcasses of bovine animals slaughtered in the region of Salvador, proving definitively the circulation of the infectious agent in the Bahian territory. These isolates were designated as Spoligotypes SB1055, SB0120, and SB0268, already described in Brazil and in other countries (COSTA et al., 2010; RODRIGUEZ et al., 2004).

Studies conducted in the 12 Federative Units of Brazil, which account for $70 \%$ of the Brazilian bovine herd, showed a prevalence of infected herds from $0.36 \%$ in the Distrito Federal to $9.0 \%$ in São Paulo (BARBIERI et al., 2016; DIAS et al., 2016; GALVIS et al., 2016; GUEDES et al., 2016; LIMA 
et al., 2016; NÉSPOLI et al., 2016; QUEIROZ et al., 2016; RIBEIRO et al., 2016; ROCHA et al., 2016; SILVA et al., 2016; BAUMGARTEN et al., 2016; VENDRAME et al., 2016).

Considering the importance of the PNCEBT in assuring productive chains of bovine meat and milk in the State of Bahia and the scarcity of data regarding the epidemiological situation of bovine tuberculosis, the present study aimed to estimate the prevalence of bovine tuberculosis as well as to determine the risk factors associated with the disease, generating good quality information to allow a rational fight against the disease in the State.

\section{Materials and Methods}

The development of the study was performed in collaboration with the Ministry of Agriculture, Livestock and Supply (MAP), the State Agency for Livestock Defence of Bahia (ADAB), and the Collaborating Center in Animal Health, located in the Faculty of Veterinary Medicine and Zootechny of the University of São Paulo (USP). Between October 2008 and November of 2010, fieldwork was performed by technicians of $\mathrm{ADAB}$, duly trained for homogenization of procedures.

The State of Bahia was initially divided into regions with homogeneous characteristics, taking into account the different production systems, management practices, purposes of cultivation, average size of herds, and marketing systems. This division also took into account the operational capacity of the official veterinary service of the State.

Two-stage sampling was performed to allow estimation of the prevalence of infected herds in the regions and in the State. In the first stage, within each region, a pre-established number of properties with reproductive activity was randomly selected from the registry of ADAB properties. In the second stage, within each property, a pre-established number of cows with age equal to or greater than 24 months was randomly selected. In the properties with separate herds, only the predominant one, that with the highest economic value or considered as the main objective of production, was the target of study. This herd was defined as a grouping of animals maintained under the same management practices, i.e., exposed to equal risk factors. Selected properties that could not be sampled for any reason were replaced with a new randomized selection. The number of selected properties per region was estimated by the formula for simple random sampling (THRUSFIELD, 2007), according to the following parameters: estimated prevalence of $20 \%, 95 \%$ confidence level, and $5 \%$ error.

For the selection of animals within each property, the amount of bovine animals to be examined was calculated to classify them as an infected herd or free of tuberculosis, considering an aggregate sensitivity equal to or greater than $85 \%$ and an aggregate specificity equal or superior to $95 \%$. The individual values of sensitivity and specificity adopted were $80 \%$ and $99.5 \%$, respectively. The calculations were performed with the aid of the Herdacc program, version 3.0.

In properties with up to 99 breeding cows with age equal to or greater than 24 months, 20 cows were tested. In properties with 100 or more cows, 40 were tested. These animals were always randomly selected from the sample and those within 15 days prior and subsequent to delivery were replaced.

The animals of the sample were subjected to the intradermal comparative cervical tuberculin diagnostic test conducted in accordance with the Technical Manual of the National Program for the Control and Eradication of Brucellosis and Tuberculosis (LAGE et al., 2006). To avoid the presence of suspect animals at the end of the study, animals with inconclusive results were retested with the same diagnostic procedure within a minimum interval of 60 days. All positive animals were euthanized.

For the properties with up to 20 bovine animals tested, the finding of one positive result was enough to classify them as a herd infected with tuberculosis. 
For those in which 40 animals were tested, the finding of at least two animals with positive results was required in order to classify them as an infected herd.

For each region as well as for the entire State, the prevalence of herds infected with bovine tuberculosis were obtained. The prevalence of infected herds within each region was also stratified by the type of farming. The calculations of apparent prevalence and the respective confidence intervals were performed as recommended by Dean et al. (1994). The calculations of prevalence of infected herds and positive animals in the State, and the prevalence of positive animals within the regions were performed in a weighted form (DOHOO et al., 2003). The weight of each property in calculating the prevalence of infected herds in the State was given by the expressions:

Properties with reproductive activity in the

$$
P_{1}=\frac{\text { Properties with reproductive activity in the }}{\text { region }}
$$

The weight of each animal in calculating the prevalence of infected herds in the State was given by:

$P_{2=} \frac{\text { Cows } \geq 24 \text { months on the property }}{\text { Cows } \geq 24 \text { months sampled on the property }} \times$
$\frac{\text { Cows } \geq 24 \text { months in the region }}{\text { Cows } \geq 24 \text { months sampled in the region }}$

In the expressions above, the first term refers to the weight of each animal in the calculation of the prevalence of infected herds within the regions. Calculations were performed using the SPSS program, version 20 .

In all of the properties selected for the study, a questionnaire was also administered to individualize the risk factors associated with an infected herd. The questionnaire was formulated to determine the existence of exposure to classic risk factors, already described in the literature (MARANGON et al., 1998; RAMÍREZ-VILLAESCUSA et al., 2010, SKUCE et al., 2012), as well as others of particular regional interest. The questions addressed the following variables: type of farm (beef, dairy, or mixed); degree of agglomeration of animals (confined, semi-confined, and open range); number and breed of the animals; use of mechanical milking and artificial insemination; form of milk delivery; introduction of cattle; presence of other animal species on the property (domestic and wild); existence of borders with forests; routine testing for bovine tuberculosis; place of slaughter of breeding animals; sharing of pastures, waterholes/drinkers; inputs, equipment, and staff; presence of flooded areas; cattle feed with whey; and existence of veterinary assistance.

The variables were displayed on an increasing risk scale. When necessary, reclassification of these variables was performed. The category of lower risk was considered as a basis for comparison with others. The quantitative variables were reclassified in quartiles. A first exploratory data analysis was performed (univariate analysis), to select those variables with $\mathrm{p} \leq 0.20$ with the $\chi^{2}$ or Fisher's exact test, and the variables were subsequently subjected to logistic regression, as recommended by Hosmer and Lemeshow (1989). Calculations were performed using the SPSS program, version 20. All the data generated by the fieldwork were inserted in a specific database, used in epidemiological analyses.

\section{Results}

The State of Bahia was divided into four regions, represented in Figure 1. 
Figure 1. Map of the State of Bahia with the division into regions. 2010.

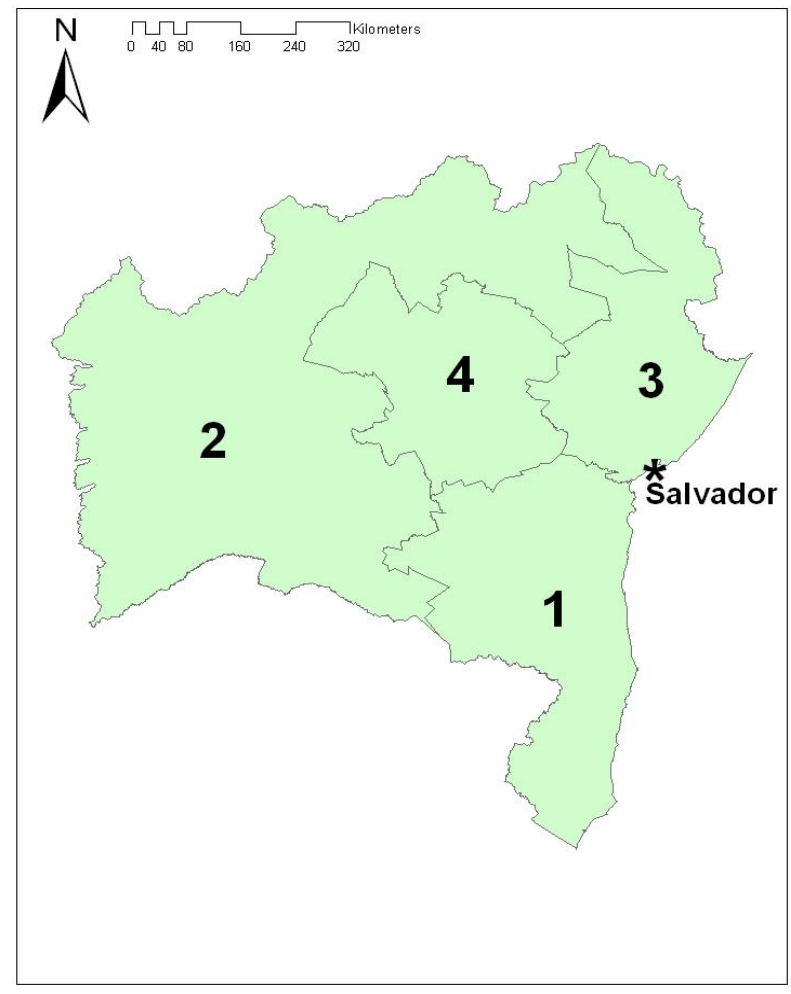

Table 1 presents the census data for the bovine population in Bahia. Table 2 shows the prevalence of infected herds. The prevalence of infected herds per type of properties is shown in Table 3. Table 4 shows the results of the univariate analysis and Table 5 displays the final logistic regression model related to the study of risk factors.

Table 1. Census data for the bovine population in the State of Bahia. 2008.

\begin{tabular}{cccccc}
\hline Regions & $\begin{array}{c}\text { Number of } \\
\text { municipalities }\end{array}$ & $\begin{array}{c}\text { Number of } \\
\text { properties with } \\
\text { bovines }\end{array}$ & $\begin{array}{c}\text { Number of } \\
\text { properties with } \\
\text { reproductive activity }\end{array}$ & $\begin{array}{c}\text { Total number of } \\
\text { bovines }\end{array}$ & $\begin{array}{c}\text { Number of cows } \\
\text { with age } \geq 24 \\
\text { months }\end{array}$ \\
\hline 1 & 132 & 60,272 & 56,184 & $4,148,603$ & $1,802,425$ \\
2 & 99 & 96,863 & 91,929 & $3,105,165$ & $1,555,317$ \\
3 & 124 & 85,448 & 68,051 & $1,929,323$ & 782,892 \\
4 & 62 & 37,300 & 31,384 & $1,149,580$ & 536,371 \\
\hline Total & 417 & 279,883 & 247,548 & $10,332,671$ & $4,677,005$ \\
\hline
\end{tabular}

Source: State Agency for Livestock Defence of Bahia, 2008. 
Table 2. Prevalence of infected herds with bovine tuberculosis in the State of Bahia. 2010.

\begin{tabular}{ccccccc}
\hline \multirow{3}{*}{ Regions } & \multicolumn{3}{c}{ Properties } & \multicolumn{3}{c}{ Cows $\geq 24$ months } \\
\cline { 2 - 7 } & $\begin{array}{c}\text { Positive / } \\
\text { sampled }\end{array}$ & Prevalence (\%) & $95 \%$ CI (\%) & $\begin{array}{c}\text { Positive / } \\
\text { sampled }\end{array}$ & Prevalence (\%) & 95\% CI (\%) \\
\hline 1 & $7 / 344$ & 2.0 & {$[1.0-4.2]$} & $8 / 6,889$ & 0.08 & {$[0.035-0.17]$} \\
2 & $9 / 308$ & 2.9 & {$[1.5-5.5]$} & $13 / 4,375$ & 0.66 & {$[0.20-2.16]$} \\
3 & $1 / 335$ & 0.3 & {$[0.04-2.1]$} & $1 / 3,210$ & 0.02 & {$[0.002-0.12]$} \\
4 & $2 / 318$ & 0.6 & {$[0.2-2.5]$} & $2 / 4,336$ & 0.05 & {$[0.01-0.20]$} \\
\hline Total & $19 / 1305$ & 1.6 & {$[1.00-2.6]$} & $24 / 18,810$ & 0.21 & {$[0.07-0.60]$} \\
\hline
\end{tabular}

CI: confidence interval.

Table 3. Prevalence of infected herds with bovine tuberculosis, stratified by type of farming in regions of the State of Bahia. 2010.

\begin{tabular}{ccccccc}
\hline \multirow{2}{*}{ Regions } & \multicolumn{2}{c}{ Beef } & \multicolumn{2}{c}{ Dairy } & \multicolumn{2}{c}{ Mixed } \\
\cline { 2 - 7 } & $\begin{array}{c}\text { Prevalence } \% \\
(\mathrm{p} / \mathrm{e})^{1}\end{array}$ & $95 \%$ CI $(\%)$ & $\begin{array}{c}\text { Prevalence \% } \\
(\mathrm{p} / \mathrm{e})\end{array}$ & $95 \%$ CI $(\%)$ & $\begin{array}{c}\text { Prevalence \% } \\
(\mathrm{p} / \mathrm{e})\end{array}$ & $95 \%$ CI $(\%)$ \\
\hline 1 & $0.0(0 / 90)$ & {$[0.0-3.24]^{2}$} & $3.7(5 / 135)$ & {$[1.2-8.43]$} & $1.7(2 / 119)$ & {$[0.2-5.93]$} \\
2 & $0.8(1 / 128)$ & {$[0.02-4.28]$} & $7.5(4 / 53)$ & {$[2.1-18.2]$} & $3.2(4 / 126)$ & {$[0.87-7.92]$} \\
3 & $0.0(0 / 145)$ & {$[0.0-2.03]^{2}$} & $0.0(0 / 63)$ & {$[0.0-1.54]^{2}$} & $0.8(1 / 127)$ & {$[0.02-4.3]$} \\
4 & $0.0(0 / 128)$ & {$[0.0-2.29]^{2}$} & $1.2(1 / 80)$ & {$[0.03-6.77]$} & $0.9(1 / 110)$ & {$[0.02-4.96]$} \\
\hline
\end{tabular}

${ }^{1}$ positive/examined, ${ }^{2}$ Monte Carlo simulation for beta distribution.

CI: confidence interval.

Table 4. Results of the univariate analysis of possible risk factors for bovine tuberculosis $(p \leq 0.20)$ in the State of Bahia. 2010.

\begin{tabular}{lcccc}
\hline \multicolumn{1}{c}{ Variable } & $\begin{array}{c}\text { Total number of } \\
\text { properties }\end{array}$ & $\begin{array}{c}\text { Number of infected } \\
\text { properties }\end{array}$ & $\%$ & $\mathrm{p}$ value \\
\hline $\begin{array}{l}\text { Number of cows with age } \geq 24 \text { months } \\
\text { Up to } 17\end{array}$ & 742 & 2 & 0.27 & $<0.0001$ \\
$\geq 18$ & 563 & 17 & 3.02 & \\
Type of farming & & & & 0.004 \\
Beef & 491 & 1 & 0.2 & \\
Dairy & 331 & 10 & 3.02 & \\
Mixed & 482 & 8 & 1.66 & \\
Having veterinary assistance & & & & 0.03 \\
No & 1126 & 12 & 1.07 & \\
Yes & 172 & 6 & 3.49 & \\
Presence of wild animals & & & & 0.064 \\
No & 618 & 3 & 0.49 & \\
Yes & 687 & 6 & 0.87 & \\
Breed & & & & 0.084 \\
Zebu cows & 358 & 1 & 0.28 & \\
European dairy & 75 & 3 & 4 & \\
European beef & 2 & 0 & 0 & \\
Mestizo & 823 & 15 & 1.82 & \\
Other races & 41 & 0 & 0 &
\end{tabular}

continue 
continuation

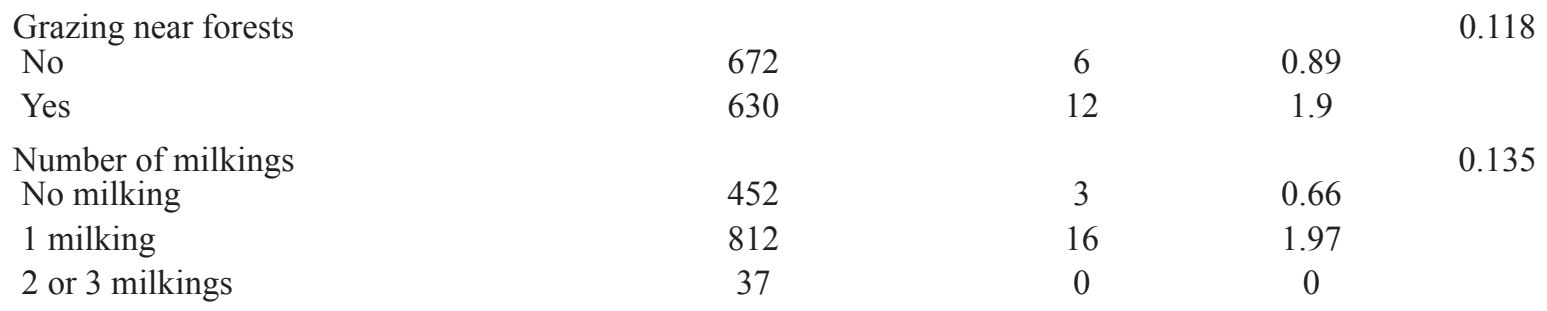

Table 5. Final multivariate logistic regression model for the risk factors for bovine tuberculosis in the State of Bahia. 2010.

\begin{tabular}{lccc}
\hline \multicolumn{1}{c}{ Variable } & OR & $95 \%$ CI & p value \\
\hline Dairy farm & 9.72 & $1.22-77.6$ & 0.03 \\
Mixed farm & 6.66 & $0.81-54.5$ & 0.07 \\
Number of cows $\geq 24$ months $\geq 18$ & 8.44 & $1.9-37.4$ & 0.005 \\
\hline
\end{tabular}

OR: odds ratio; CI: confidence interval.

\section{Discussion}

The prevalence of infected herds for the entire State was $1.6 \%$ (95\% confidence interval [CI]: 1.00 2.6) (Table 2), which is equal to those observed in the States of Paraná, Rio Grande do Sul, Mato Grosso, Mato Grosso do Sul, Rondônia, Goiás, Pernambuco, and the Distrito Federal. It exceeds the prevalence of infected herds in Santa Catarina and is lower than those observed in São Paulo, Minas Gerais, and Espírito Santo (BARBIERI et al., 2016; DIAS et al., 2016; GALVIS et al., 2016; GUEDES et al., 2016; LIMA et al., 2016; NÉSPOLI et al., 2016; QUEIROZ et al., 2016; RIBEIRO et al., 2016; ROCHA et al., 2016; SILVA et al., 2016; BAUMGARTEN et al., 2016; VENDRAME et al., 2016).

The prevalence of infected herds in Regions 1 and 2 was higher than those in Regions 3 and 4, indicating that bovine tuberculosis is distributed heterogeneously within the State (Table 2).

With respect to the type of farm, Table 3 shows evidence of concentration of the infection in dairy and/or mixed farms. The association between bovine tuberculosis and dairy production has been observed by several authors (GALVIS et al., 2016; PORPHYRE et al. 2008; RAMÍREZVILLAESCUSA et al., 2010; ZENDEJAS MARTÍNEZ et al., 2007; ZENDEJAS-MARTÍNEZ et al., 2008) and this association may be attributed to factors inherent to this type of production, described as predisposing to the disease, such as high-density (CLEAVELAND et al., 2007; HUMBLET et al., 2010; OLIVEIRA et al., 2008) and a long productive cycle (BIFFA et al., 2011; REGASSA et al., 2010).

Region 2 showed a higher prevalence of infected animals than that observed in the other regions; however, the prevalence of infected animals for the entire State of Bahia (0.21\% [95\% CI: 0.07-0.60], Table 2) is among the lowest recorded by recent studies conducted in the above-mentioned Brazilian States.

Table 5 indicates that the risk factors for bovine tuberculosis in the State were dairy or mixed farming, corroborating the data of Table 3, as well as the presence of more than 18 cows in the herd.

Herds of dairy and mixed farms are more vulnerable to tuberculosis, because milk production features the agglomeration of animals on the occasion of milking, which increases the risk of 
transmission (BARLOW et al., 1997), since it raises the population density and consequently the probability of infectious contacts (HUMBLET et al., 2010; ALVAREZ et al., 2012). Dairy cattle were also found to feature a higher risk for tuberculosis in New Zealand (PORPHYRE et al., 2008), the United Kingdom (RAMÍREZ-VILLAESCUSA et al., 2010; KAROLEMEAS et al., 2011), and Brazil (GALVIS et al., 2016; DIAS et al., 2016; QUEIROZ et al., 2016; ROCHA et al., 2016; SILVA et al., 2016; VELOSO et al., 2016). In addition, animals from dairy herds tend to be older than animals from beef herds, therefore having a greater likelihood of exposure to the infectious agent (HUMBLET et al., 2009).

The fact that properties with a larger number of animals presented a higher probability of tuberculosis infection was also verified in the Republic of Ireland (GRIFFIN et al., 1996; CLEGG et al., 2012), the United Kingdom (REILLY; COURTENAY, 2007; RAMÍREZ-VILLAESCUSA et al., 2010; BESSELL et al., 2012), New Zealand (PORPHYRE et al., 2008), and Brazil (GALVIS et al., 2016; DIAS et al., 2016; SILVA et al., 2016; BAUMGARTEN et al., 2016). Larger herds have a higher rate of restocking, thus increasing the risk of introduction of infected herds. The purchase of new animals, in particular from risky properties, is of central importance in the transmission of bovine tuberculosis (REILLY; COURTENAY, 2007; OLOYA et al., 2007; TSCHOPP et al., 2009; RAMÍREZ-VILLAESCUSA et al., 2010; SKUCE et al., 2012; BESSELL et al., 2012). Thus, it is plausible to assume that this variable indicates that the purchase of new animals, naturally without prior testing, signifies expansion of the risk of introduction of bovine tuberculosis in a property.

\section{Conclusion}

In conclusion, it is recommended that the State of Bahia implement a surveillance system for the detection of herds with bovine tuberculosis to certifying them in free herds, with special attention to dairy properties, and develop a solid program of health education so that producers test animals for bovine tuberculosis before introducing them into their herds.

\section{Acknowledgements}

The authors acknowledge the logistical and financial support from MAPA, ADAB, CNPq and FAPESP.

\section{References}

ALVAREZ, J.; PEREZ, A M.; BEZOS, J.; CASAL, C.; ROMERO, B.; RODRIGUEZ-CAMPOS, S.; SAEZLLORENTE, J. L.; DIAZ, R.; CARPINTERO, J.; DE JUAN, L.; DOMÍNGUEZ, L. Eradication of bovine tuberculosis at a herd-level in Madrid, Spain: study of within-herd transmission dynamics over a 12 year period. BMC Veterinary Research, v. 8, n. 100, p. 2-8, 2012. Available in: <http://www.biomedcentral.com/content/ pdf/1746-6148-8-100.pdf $>$. Acesso em: 05 jan. 2016.

ALVES, A. J. S.; GONÇALVES, V. P. S.; FIGUEIREDO, V. C. F.; LÔBO, J. R.; BAHIENSE, L.; AMAKU, M.; FERNANDO, F.; FERREIRA NETO, J. S.; DIAS, R. A. Situação epidemiológica da brucelose bovina no Estado da Bahia. Arquivo Brasileiro de Medicina Veterinária e Zootecnia, Belo Horizonte, v. 61, p. 6-13, 2009. Suplemento 1.

BARBIERI, J. M.; OLIVEIRA, L. F.; DORNELES, E. M. S.; MOTA, A. L. A. A.; GONÇALVES, V. S. P.; MALUF, P. P.; FERREIRA NETO, J. S.; FERREIRA, F.; DIAS, R. A.; TELLES, E. O.; GRISI-FILHO, J. H. H.; HEINEMANN, M. B.; AMAKU, M.; LAGE, A. P. Epidemiological status of bovine tuberculosis in the state of Minas Gerais, Brazil. Semina: Ciências Agrárias, Londrina, v. 37, n. 5, p. 3531-3548, 2016. Suplemento 2.

BARLOW, N. D.; KEAN, J. M.; HICKLING, G.; LIVINGSTONE, P. G.; ROBSON, A. B. A simulation model for the spread of bovine tuberculosis within New Zealand cattle herds. Preventive Veterinary Medicine, v. 32, n. 1-2, p. 57-75, 1997.

BESSELL, P. R.; ORTON, R.; WHITE, P. C. L.; HUTCHINGS, M. R.; KAO, R. R. Risk factors for bovine Tuberculosis at the national level in Great Britain. BMC Veterinary Research, v. 8, p. 51, 2012. Available at: $\quad<$ http://www.biomedcentral.com/1746-6148/8/51>. Acesso em: 05 jan. 2016. 
BIFFA, D.; INANGOLET, F.; BOGALE, A.; OLOYA, J.; DJØNNE, B.; SKJERVE, E. Risk factors associated with prevalence of tuberculosis-like lesions and associated mycobacteria in cattle slaughtered at public and export abattoirs in Ethiopia. Tropical Animal Health and Production, v. 43, n. 2, p. 529-538, 2011.

CLEGG, T. A.; BLAKE, M.; HEALY, R.; GOOD, M.; HIGGINS, I. M.; MORE, S. J. The impact of animal introductions during herd restrictions on future herdlevel bovine tuberculosis risk. Preventive Veterinary Medicine, v. 109, n. 3-4, p. 246-257, 2012.

COSTA, A. C. F.; SILVA, N. S.; ROCHA, V. C. M.; ROSALES RODRIGUEZ, C. A.; ESTRELA-LIMA, MOREIRA, E. L. T.; MADRUGA, C.; ARRUDA, S. M.; FERREIRA NETO, J. S.; SILVA, M. C. A.; OLIVEIRA, E. M D. Tipificação genética, através da técnica de spoligotyping, de isolados de Mycobacterium bovis em animais abatidos na região metropolitana de Salvador, Bahia, Brasil. Arquivos do Instituto Biológico, São Paulo, v. 77, n. 2, p. 233-237, 2010.

COSTA, J. N.; FERREIRA, M. M.; TEIXEIRA, L. L.; MENEZES, R. V.; RAMALHO, E. J. Tuberculose bovina: estudo preliminar da bacia leiteira de AlagoinhasBa. Arquivo da Escola de Medicina Veterinária da Universidade Federal da Bahia, v. 18, p. 141-148, 1995/1996.

DEAN, A. G.; DEAN, J. A; COUlOMBIER, D.; BRENDEL, K. A.; SMITH, D. C.; BURTON, A. H.; DICKER, R. C.; SULLIVAN, K.; FAGAN, R. F.; ARNER, T. G. Epi Info 6.: a word processing database, and statistics program for epidemiology on microcomputers. Atlanta: Center for Diseases Control and Prevention, 1994. 601 p.

DIAS, R. A.; STANOJLOVIC, F. M. U.; BELCHIOR, A. P. C.; FERREIRA, R. S.; GONÇALVES, R. C.; AGUIAR, R. S. C. B.; SOUSA, P. R.; SANTOS, A. M.A.; AMAKU, M.; FERREIRA, F.; TELLES, E. O.; GRISI-FILHO, J. H. H.; GONÇALVES, V. S. P.; HEINEMANN, M. B.; FERREIRA NETO, J. S. Prevalence and risk factors for bovine tuberculosis in the state of São Paulo, Brazil. Semina: Ciências Agrárias, Londrina, v. 37, n. 5, p. 3673-3684, 2016. Suplemento 2.

DOHOO, I.; MARTIN, W.; STRYHN, H. Veterinary epidemiologic research. Charlottetown: Atlantic Veterinary College, 2003. 706 p.

GALVIS, J. O. A.; GRISI-FILHO, J. H. H.; COSTA, D.; SAID, A. L. P. R.; AMAKU, M.; DIAS, R. A.; FERREIRA, F.; GONÇALVES, V. S. P.; HEINEMANN, M. B.; TELLES, E. O.; FERREIRA NETO, J. S. Epidemiologic characterization of bovine tuberculosis in the state of Espírito Santo, Brazil. Semina: Ciências Agrárias, Londrina, v. 37, n. 5, p. 3567-3578, 2016. Suplemento 2.

GRIFFIN, J. M.; MARTIN, S. W.; THORBURN, M. A. A case-control study on the association of selected risk factors with the occurrence of bovine tuberculosis in the Republic of Ireland Preventive Veterinary Medicine, v. 27, n. 34, p. 217-229, 1996.

GUEDES, I. B.; BOTTENE, I. F. N.; MONTEIRO, L. A. R. C.; LEAL FILHO, J. M.; HEINEMANN, M. B.; AMAKU, M.; GRISI-FILHO, J. H. H.; DIAS, R. A.; FERREIRA, F.; TELLES, E. O.; GONÇALVES, V. S. P.; FERREIRA NETO, J. S. Prevalence and risk factors for bovine tuberculosis in the state of Mato Grosso do Sul, Brazil. Semina: Ciências Agrárias, Londrina, v. 37, n. 5, p. 3579-3588, 2016. Suplemento 2.

HOSMER, D. W.; LEMESHOW, S. Applied logistic regression. New York: John Wiley and Sons, 1989. 307 p.

HUMBLET, M.F.; BOSCHIROLI, M.L.; SAEGERMAN, C. Classification of worldwide bovine tuberculosis risk factors in cattle: a stratified approach. Veterinary Research, v. 40, n. 5, p. 50, 2009. Available at: <http:// www.ncbi.nlm.nih.gov/pmc/articles/PMC2710499>. Accessed at: 05 jan. 2016.

HUMBLET, M. F.; GILBERT, M.; GOVAERTS, M.; FAUVILLE-DUFAUX, M.; WALRAVENS, K.; SAEGERMAN, C. New assessment of bovine tuberculosis risk factors in Belgium based on nationwide molecular epidemiology. Journal of Clinical Microbiology, v. 48, n. 8, p. 2802-2808, 2010.

INSTITUTO BRASILEIRO DE GEOGRAFIA E ESTATÍSTICA - IBGE. Pesquisa Pecuária Municipal. Brasília: IBGE, 2011. Disponível em: < http://www.sidra. ibge.gov.br/bda/tabela/listabl.asp?c=73\&z=p\&o $=29>$. Acesso em: 05 jan. 2016.

KAROLEMEAS, K.; MCKINLEY, T. J.; CLIFTONHADLEY, R. S.; GOODCHILD, A. V.; MITCHELL, A.; JOHNSTON, W. T.; CONLAN, A. J.; DONNELLY, C. A.; WOOD, J. L. Recurrence of bovine tuberculosis breakdowns in Great Britain: risk factors and prediction. Preventive Veterinary Medicine, v. 102, n. 1, p. 22-29, 2011.

LAGE, A. P.; ROXO, E.; MÜLLER, E.; POESTER, F.; CAVALLÉRO, J. C. M.; FERREIRA NETO, J. S.; MOTA, P. M. P. C.; GONÇALVES, V. S. P. Programa nacional de controle e erradicação da brucelose e da tuberculose animal (PNCEBT). Brasília: Ministério da Agricultura, Pecuária e Abastecimento (MAPA), 2006. 184 p. (Manual técnico). 
LIMA, P. B.; NASCIMENTO, D. L.; ALMEIDA, E. C.; PONTUAL, K. A. Q.; AMAKU, M.; DIAS, R. A.; FERREIRA, F.; GONÇALVES, V. S. P.; TELLES, E. O.; GRISI-FILHO, J. H. H.; HEINEMANN, M. B.; SILVA, J. C. R.; FERREIRA NETO, J. S. Epidemiological situation of bovine tuberculosis in the state of Pernambuco, Brazil. Semina: Ciências Agrárias, Londrina, v. 37, n. 5, p. 3601-3610, 2016. Suplemento 2.

MARANGON, S.; MARTINI, M.; DALLA POZZA, M.; FERREIRA NETO, J. S. A case-control study on bovine tuberculosis in the Veneto region, Italy. Preventive Veterinary Medicine, v. 34, n. 2, p. 87-95, 1998.

NÉSPOLI, J. M. B.; NEGREIROS, R. L.; AMAKU, M.; DIAS, R. A.; FERREIRA, F.; TELLES, E. O.; HEINEMANN, M. B.; GRISI-FILHO, J. H. H.; GONÇALVES, V. S. P.; FERREIRA NETO, J. S. Epidemiological situation of bovine tuberculosis in the state of Mato Grosso, Brazil. Semina: Ciências Agrárias, Londrina, v. 37, n. 5, p. 3589-3600, 2016. Suplemento 2.

OLIVEIRA, V. M.; FONSECA, A. H.; PEREIRA, M. J. S.; CARNEIRO, A. V.; JESUS, V. L. T.; ALVES P. A. M. Análise retrospectiva dos fatores associados à distribuição da tuberculose bovina no Estado do Rio de Janeiro. Arquivo Brasileiro de Medicina Veterinária e Zootecnia, Belo Horizonte, v. 60, n. 3, p. 574-579, 2008.

OLOYA, J.; MUMA, J. B.; OPUDA-ASIBO, J.; DJØNNE，B.; KAZWALA，R.; SKJERVE，E. Risk factors for herd-level bovine-tuberculosis seropositivity in transhumant cattle in Uganda. Preventive Veterinary Medicine, v. 80, n. 4, p. 318-29, 2007.

PORPHYRE, T.; STEVENSON, M. A.; MCKENZIE, J. Risk factors for bovine tuberculosis in New Zealand cattle farms and their relationship with possum control strategies. Preventive Veterinary Medicine, v. 86, n. 1-2, p. 93-106, 2008.

QUEIROZ, M. R.; GROFF, A. C. M.; SILVA, N. S.; GRISI-FILHO, J. H. H.; AMAKU, M.; DIAS, R. A.; TELLES, E. O.; HEINEMANN, M. B.; FERREIRA NETO, J. S.; GONÇALVES, V. S. P. FERREIRA, F. Epidemiological status of bovine tuberculosis in the state of Rio Grande do Sul, Brazil. Semina: Ciências Agrárias, Londrina, v. 37, n. 5, p. 3647-3658, 2016. Suplemento 2.

RAMÍREZ-VILLAESCUSA, A. M.; MEDLEY, G. F.; MASON, S.; GREEN, L. E. Risk factors for herd breakdown with bovine tuberculosis in 148 cattle herds in the South West of England. Preventive Veterinary Medicine, v. 95, n. 3-4, p. 224-230, 2010.

REGASSA, A.; TASSEW, A.; AMENU, K.; MEGERSA, B.; ABUNNA, F.; MEKIBIB, B.; MACROTTY, T.; AMENI, G. Across-sectional study on bovine tuberculosis in Hawassa town and its surroundings, Southern Ethiopia. Tropical Animal Health and Production, v. 42, n. 5, p. 915-920, 2010.

REILLY, L. A.; COURTENAY, O. Husbandry practices, badger sett density and habitat composition as risk factors for transient and persistent bovine tuberculosis on UK cattle farms. Preventive Veterinary Medicine, Colorado, v. 80, n. 2-3, p. 129-142, 2007.

RIBEIRO, A. R. P.; LOBATO, F. C. F.; ABREU, V. L. V.; FARIA, E. S.; SILVA, J. A. Prevalência de tuberculose e brucelose bovina no município de Ilhéus. Arquivo Brasileiro de Medicina Veterinária e Zootecnia, Belo Horizonte, v. 55, n. 1, p. 120-122, 2003. (Comunicação).

RIBEIRO, L. A.; GONÇALVES, V. S. P.; FRANCISCO, P. F. C.; MOTA, A. L. A. A.; NASCIMENTO, G. T.; LICURGO, J. B.; FERREIRA, F.; GRISI-FILHO, J. H. H.; FERREIRA NETO, J. S.; AMAKU, M.; DIAS, R. A.; TELLES, E. O.; HEINEMANN, M. B.; BORGES, J. R. J. Epidemiological status of bovine tuberculosis in the Federal District of Brazil. Semina: Ciências Agrárias, Londrina, v. 37, n. 5, p. 3561-3566, 2016. Suplemento 2.

ROCHA, W. V.; JAYME, V. S.; MOTA, A. L. A. A.; BRITO, W. M. E. D; PIRES, G. R. C; GRISI-FILHO, J. H. H; DIAS, R. A.; AMAKU, M.; TELLES, E. O.; HEINEMANN, M. B.; FERREIRA, F.; FERREIRA NETO, J. S.; GONÇALVES, V. S. P. Prevalence and herd-level risk factors of bovine tuberculosis in the State of Goiás, Brazil. Semina: Ciências Agrárias, Londrina, v. 37, n. 5, p. 3625-3628, 2016. Suplemento 2.

RODRIGUEZ, C. A. R.; ZUMÁRRAGA, M. J.; OLIVEIRA, E. M. D.; CATALDI, A. A.; ROMANO, M. I.; OTTO, H. H.; BONAFÉ, V. L.; FERREIRANETO, J. S. caracterização molecular de isolados de Mycobacterium bovis do estado de São Paulo, Brasil, utilizando a técnica de spoligotyping. Arquivos do Instituto Biológico, São Paulo, v. 71, n. 3, p. 277-282, 2004.

SILVA, M. C. P.; GONÇALVES, V. S. P.; MOTA, A. L. A. A.; KOLODA, M.; FERREIRA NETO, J. S.; GRISIFILHO, J. H. H; DIAS, R. A.; AMAKU, M.; TELLES, E. O.; FERREIRA, F.; HEINEMANN, M. B.; ALFIERI, A. A.; MULLER, E. E. Prevalence and herd-level risk factors for bovine tuberculosis in the state of Paraná, Brazil. Semina: Ciências Agrárias, Londrina, v. 37, n. 5, p. 3611-3624, 2016. Suplemento 2.

SKUCE, R. A.; ALLEN, A. R.; MCDOWELL, S. W. J. Herd-level risk factors for bovine tuberculosis: a literature review Herd-level risk factors for bovine tuberculosis: a literature review. Veterinary Medicine International, v. 2012, Article ID 621210, 10 pages, 2012. Available at: $<$ http://www.hindawi.com/journals/vmi/2012/621210/ abs/>. Acesso em: 05 jan. 2016. 
THRUSFIELD, M. Veterinary epidemiology. $3^{\text {th }}$ ed. Cambridge: Blackwell Science, 2007. 610 p.

TSCHOPP, R.; SCHELLING, E.; HATTENDORF, J.; ASEFFA, A.; ZINSSTAG, J. Risk factors of bovine tuberculosis in cattle in rural livestock production systems of Ethiopia. Preventive Veterinary Medicine, Colorado, v. 89, n. 3-4, p. 205-11, 2009.

VELOSO, F. P.; BAUMGARTEN, K. D.; MOTA, A. L. A. A.; FERREIRA, F.; FERREIRA NETO, J. S.; GRISI-FILHO, J. H. H.; DIAS, R. A.; AMAKU, M.; TELLES, E. O.; HEINEMANN, M. B.; GONÇALVES, V. S. P. Prevalence and herd-level risk factors of bovine tuberculosis in the State of Santa Catarina, Brazil. Semina: Ciências Agrárias, Londrina, v. 37, n. 5, p. 3659-3672, 2016. Suplemento 2.
VENDRAME, F. B.; AMAKU, M.; FERREIRA, F.; TELLES, E. O.; GRISI-FILHO, J. H. H.; GONÇALVES, V. S. P.; HEINEMANN, M. B.; FERREIRA NETO, J. S.; DIAS, R. A.; Epidemiologic characterization of bovine tuberculosis in the State of Rondônia, Brazil. Semina: Ciências Agrárias, Londrina, v. 37, n. 5, p. 3639-3646, 2016. Suplemento 2.

ZENDEJAS MARTÍNEZ, H.; MILIAN SUAZO, F.; CUADOR GIL, J. Q.; CRUZ BELLO, G.; ANAYA ESCALERA, A. M.; HUITRÓN MÁRQUEZ, G.; GARCÍA CASANOVA, L. Spatial epidemiology of bovine tuberculosis in Mexico. Veterinaria Italiana, v. 43, n. 3, p. 629-634, 2007.

ZENDEJAS-MARTÍNEZ, H.; TOWNSEND, A. P.; MILIÁN-SUAZO, F. Coarse-scale spatial and ecological analysis of tuberculosis in cattle: an investigation in Jalisco, Mexico. Geospatial Health, v. 3, n. 1, p. 29-38, 2008. 
